\title{
Upholding the Igbo Cultural Heritage through the Theatre
}

\author{
Christian Ikechukwu Nwaru \\ University of Northampton, Northampton, UK \\ Email: chrisnwaru@yahoo.com
}

Received 9 February 2015; accepted 13 April 2015; published 15 April 2015

Copyright (C) 2015 by author and Scientific Research Publishing Inc.

This work is licensed under the Creative Commons Attribution International License (CC BY). http://creativecommons.org/licenses/by/4.0/

cc) (i) Open Access

\begin{abstract}
This paper starts with explaining the meaning of culture and cultural heritage. The researcher discusses the relevance's of some of the material culture of the Igbo people, and how such materials could be preserved through the theatre. The development, presentation and preservation of Igbo art, Igbo symbol, Igbo mask, Igbo sound symbol, Igbo literature, Igbo festival and ceremonies through the theatre become necessary for advancement. A look at archival materials on Igbo art led to the submission that the Igbo and Nigeria artists can as a matter of fact draw inspiration from our rich arts and culture for better performances.
\end{abstract}

\section{Keywords}

Upholdıng, Igbo, Cultural Heritage, Through, Theatre

\section{Introduction}

One world likes to begin by looking at the meaning of cultural heritage or perhaps it will be better to start with explaining what culture means. Studies on culture and human nature have shown that at the core of man's being is culture. Culture is man's way of being human especially in relation to others. Culture is substantial and should not be seen as an abstract object. It is the way of life of a people. Definitions of culture are as numerous as there are many authentic studies of culture. The Oxford Dictionary of Language Matters (2015) defines culture as the ideas, customs, and social behaviour of a particular people or society. According to Bakare (2006), culture is the totality of the way of life a people evolve to meet with the exigencies of survival. The knowledge and skills needed for meeting such needs may be contained in an already existing corpus of practices, or they may be framed in response to unfolding exigencies. One of our closest and probably easiest reference points is the Cultural Policy for Nigeria which defines culture as: 
The totality of way of life evolved by a people in their attempt to meet the challenges of their environment which gives its order and meaning. Their social, politics, economics, aesthetic and religious norms and modes of organization, and thus distinguishing a people from their neighbours (1998: 11).

Two phrases are very significant in the above explanation, namely, "way of life" and "distinguishing a people from their neighbours". The Igbo expression "omenala", which means our culture and tradition, throws more light on this explanation. "Ahamefule", which could be translated as my name should not be lost, is another Igbo expression that adds meaning to our explanation of culture because it borders on identity. Perhaps, being more concrete would make our explanation of culture more vivid. Culture includes our arts and artifacts, crafts, folktales, folksongs and poetry, music, dance, beliefs, ideas, occupation, technology etc, they are handed from generation to generation through socialization and education, and are our cultural heritage. In his contribution on cultural area, Onwuejeogwu (1975: p. 1) defined it as "a geographic delimitation of areas that have the same dominant and significant culture traits, complexes and patterns". Culture comprises material, institutional, philosophical and creative aspects. The material aspect has to do with artifacts in its broadest form (namely; tools, clothing, food, medicine, utensils and housing). The institutional deals with the political, economic, social and legal structures erected to help achieve material and spiritual objectives; while the philosophical is concerned with a people's literature (oral or written) as well as their visual and performing arts which are normally molded by, as well as help to mold other aspects of culture. In the light of the above, one can attempt a working definition of culture as the pattern of all the arrangements (both material and behavioural), which have been adopted by a society as the traditional ways of solving the problems of its members. A deep search for the underlying principles of culture shows that most groups in Nigeria behave alike. All culture is a way of life and the culture of one ethnic group is never superior to that of another. The way certain things are said or done may differ from one culture area to another, but the basic principles involved may be the same. In the Igbo society, some of the above mentioned elements of culture were passed from one generation to another and could be preserved through the theatre.

Cultural heritage is the focus of this paper can be defined as those attributes, behavioural patterns, lifestyles, social structures and norms that are passed on laterally or inherited from one generation to another (Omekwu, 2003). It is therefore the basis for the existence of any ordered human society. It is the collective property of any people which should be cherished and nurtured for the perpetuation of a healthy society. No wonder why our forefathers evolved a more orderly society than we have now, in spite of our exaggerated technological advancement or modernity. It was not therefore surprise when our revered author-late professor Chinua Achebe (1980) in his book Things Fall Apart lamented that: "the white had put knife in the thing that held us together and things have fallen apart”.

\section{Who Are the Igbo?}

The Igbo occupy the South-East zone in Nigeria. Igbo origin is steeped in controversy; some of the oral accounts by historians and anthropologists claim the Igbo are primordial people (Isichei, 1976) in South Eastern Nigeria. Onwuejeogwu (1978) suggests that their ancestral forebears settled the people and culture known today as Igbo in-land at the centre of Nigeria's eastern region. Some commentators link Igbo origin to Egypt, North Africa and Israel (Ezeabasili, 1982; Afigbo, 1987; Ohadike, 1994). Today Igbo-speaking people live all over Nigeria and in diverse countries of the world. Presently, they constitute the entire Enugu, Anambra, Abia, Ebonyi, and Imo States, the Ahoada area of Rivers State and Bonny and Obudu of Cross River State (Afigbo, 1981; Isichei, 1976; Ukaegbu, 2007). Igbo-speaking people west of the Niger live in Asaba, Ika, and Agbo areas of Delta State. Various estimates have been given for the size of the Igbo population in Nigeria: 13 million according to a 1991 census (Cycle, 1995), 23 million (Serge, 1991), and 50 million (Ihejirika, 2010). Other Igbo sub-groups with distinct Igbo language dialects also inhabit the northern parts of AkwaIbom to the south. Ukaegbu (2007) notes that the spread of communities in Igbo heartland and beyond and their interaction with neighbouring people account for the cultural affinities as well as the aesthetic flexibility that characterises Igbo performances including dance form.

The Igbo are one of the four largest ethnic groups in Nigeria and are the major people-group in eastern Nigeria. They have one of the highest population densities in West Africa, ranging from 120 to more than 400 persons per square kilometer (World Directory of Minorities, 1997: pp. 444-445). The word Igbo is used in three senses, to describe Igbo territory, domestic speakers of the language and the language spoken by them (Ogbaa, 
1995). The Igbo has over the years, right from the colonial era through the Nigerian civil war to this time, had their culture battered and destroyed in a lamentable manner. They have not only lost their maternal culture, which were either ignorantly destroyed by the early Christians and or carefully removed by the colonial masters to different parts of the world, but their festivals, religion, tradition, norms and values, their total civilization has been badly eroded and perhaps this may have affected their behaviour or their total response to their environment. Though several of their material culture have either been destroyed or removed, a lot of their cultural heritage still remains to be preserved. According to Njoku (2009: p. 159) "culture belongs to the community and it is the community that project its culture". The researcher also thinks that it is the responsibility of the community to preserve her culture and cultural heritage through some of its agencies including theatre. Emeana (2005) opines that theatre through ages is one of the most powerful instruments of preserving and promoting culture. A dynamic perpetuation and or continuity of a people's art and culture will always involve development which comes through preservation, promotion and presentation.

\section{Igbo Arts}

The Igbo have one of the finest aesthetic, most intricate and most symbolic art the world over which needed to be popularised for other people to appreciate. According to Aniako (2002), art is any man-made aesthetic object that stimulates and elicits an emotional response from the beholder and leaves with him or her with a lasting emotional and perhaps intellectual experience. It could be a sculpture, like the masks head (artefacts) or a dance or performance. The Igbo refer to this visual encounter, in the case of masking or dancing, as ihenkiri; that is, it is a visual spectacle or something to behold because it pleases. Art has the function of enforcing the sense of identity of a particular group, and acts as a bond of unity amongst the people. There are great varieties of forms and practice of art in the Igbo region. Some are found to have value as entertainment, some have political and ideological significance, some are instrumental in a ritual context and some have aesthetic value in themselves. More often than not, a work of art from this region combines several of these elements. Some art products can be created by just anybody in so far as the people belong to that cultural setting, while others demand the devotion of professionals. According to Amankulor (2002), in the Igbo traditional setting art is a common occurrence, and there are very few homes or communities without treasures that can be dated as far back as the people's history. Igbo people recognise and appreciate the usefulness of art; hence, they have a name for it. Usefulness here implies both the utilitarian and the aesthetic. The Igbo word for art is $n k a$; hence, the artist is an omenka. To be artistic, imenka, applies to a variety of situations in life, ranging from the practice of such occupational craft as carpentry and word-carving to such activities that excite aesthetic appreciation as music, dance, and drama to occupational crafts. The carpenter, the actor, the dancer or the musician is an ome-nka in his own right and in his own context.

Like some other societies in Africa, the artistic products of the Igbos could be categorised thus: The visual, which includes sculpture, graphics and architecture, the literary which could be written or oral, and the performative which manifests itself in drama, dance and music. The Igbo people see visual arts as a way of expressing visual beauty through the decoration of the human body, or through designing physical objects which people use like baskets, expressing feelings in painting, sculpture and so on. Painting in one form or another is found throughout Igbo land. Sculptures for instance are painted, whether masks or other forms. For example, the Ijele masquerade of Anambra people is painted with different colours that represent the Igbo worldview of the universe. The Igbo arts is illustrated in their architecture, painting, sculpture, textile, designs, body decoration, pottery, mask, etc and could be preserved through the theatre.

\section{Igbo Literature}

Literary arts are associated with words as basic ingredients whether spoken or written, though literature often suggests "a book, a text in a script, a piece of writing that can be read and preserved as a document" (Ikiddeh, 2005: p. 51). Literature that has to do with the spoken word is usually termed oral literature. It derives its material from oral tradition, which is defined as testimonies and other accounts of past events that have been recorded and transmitted by eye witnesses and the inheritors of their legacies. Ikiddeh refers to oral tradition as "the body of a people's spoken culture that includes folktales, fables, myths, legends, incantations, libations and riddles... a social product which has its root in a defined cultural context” (Ikiddeh, 2005: p. 59).

Literature is the embodiment of Ibo tradition and culture. The Igbo people have immensely rich and varied 
forms of oral tradition that include the abovementioned styles. The performance of these traditional forms was not only for entertainment but ways of teaching young ones their history, religion, their environment, customs, norms and values of the society. The most important feature of these forms of oral tradition is their close link with music. Folktales, for example, have song accompaniments. The Igbo word "akukonaifo" (stories and fairy tales) covers folktales, parables, proverbs and riddles. The traditional storytelling (folktale) session of the Igbo people examines the dominant concerns of the immediate community in particular and human behaviour and the human condition in general. They may have as many versions as there are villages in the area, and the storyteller is at liberty to improvise. Also, the story is passed on by word of mouth from one generation to another. They are fictional stories that are told primarily for the purpose of entertainment, pleasure and for teaching a lesson. Some of the stories are connected with the worship of gods and commemoration of past heroes. In storytelling, the narrator imitates the characters in the tales, and this gave rise to the concept of acting. The folktales are spiced up with songs; the dramatic enactments are set to the appropriate mood through music and songs.

\section{Igbo Symbols}

Webster's reference library dictionary and thesaurus defines symbol as "A representation; an object used to represent something”. It could be a sound, writing or drawing whose suggestion is beyond it. Symbols in any culture are effective means of communication, without words Igbo like other cultures, has symbols that are generally known and others that are esoteric, i.e. those that can only be interpreted by a few (secrets symbols, e.g. those of masquerade) Igbo symbols are drawn from their environment and serve different purpose, for example:

\subsection{Status Symbols (by Age or Achievement)}

- Ivory (Aku) Wealth

- Anklet (Ozo) Title-Holder

- Eagle Feather (Abuba-Ugo) ------------- Excellence, Strength, Beauty

- Red Barrette Cap (Okpu-Obara) -------- Traditional Ruler, Chief

\subsection{Ritual-Ceremony/Mysticism}

- White Traditional Chalk (Nzu) ----------- Purity, Openness

- Yellow Tradition Chalk (Edo) ------------ Sacrifice, Vision

- Palm Fronts (Omu) --------------- Warning, Forbidding

\subsection{Sound Symbols}

- The Biggest Wooden Slit-Drum (Ikoro) ---- Burial, War

- The Medium Wooden Slit-Drum (Ufe) ----- Royalty

- The Small Wooden Slit-Drum (Ekwe) ------ Public Announcement

\subsection{Symbolic Edible Items}

- Kola and Alligator-Pepper (Oji naOse) ------ Hospitality, Friendship, Welcome

- Traditional Salad (Abacha/Ugba) ---------- ---Intimacy

\subsection{Mere Sounds}

- Cry (Akwa) ----------------------------------- Sorrow

- Laughter (Ochi) ---------------------------- Joy and Fun

- Booing (Itu-Uzu) --------------------------------- Disapproval

\section{Festivals and Ceremonies}

Festivals and ceremonies in Igbo land do not only go beyond mere recreation and entertainment, they also are a way of transmitting Igbo customs, norms and values. Festivals give expression to the crafts, technology, psychology and philosophy of a people, their social control, dance, music, religion, government etc. A few festivals 
are: Iri-Ji festival, Mbari festival, Ofoala festival, Isu-Uzo festival, Mmanwu festival, Ozuruimo festival and Ugwu-Abia festival. In Igbo society, masquerading is festival display that is connected with the supernatural world of ancestors and spirits. On the concept of Igbo masking, Ukaegbu (2007) asserts that the masking institution is perhaps the only platform in the cultural Igbo society for reinforcing and enacting the interactive relationship that it has with the numerous forces of its universe. According to Ukaegbu, "the primordial encounters' arising from this relationship provides the major focus and themes of Igbo masking” (2007: p. 30). To expound on his views on Igbo masking, Ukaegbu (2007) opines that Igbo masking sustains interactions between the seen and unseen. Concerning the interaction between the seen (humans) and the unseen (spirits), Nzekwu (1981) adds that in Igbo-land whenever masqueraders appear in performance, ancestral spirits visit mankind. The nature and contents of Igbo masking are common knowledge in every community; the stories are well-known, but the interesting thing as Ukaegbu (2007: p. 31) notes is that "the audience are sustained with the aesthetic depth and dynamism that performers bring to their re-enactments of primordial encounters and familiar action lines than in elaborates narratives". The masquerades paraded during the masquerade festivals in the different cultural zones of the Igbo region represent a wide variety of animals, suggestive gods, spirits, demons and ancestors, and the wearers play roles that are appropriate to what or who they represent.

Apart from masquerades, there are other festivals in the Igbo region. Many communities stage the new yam festival in connection with the yam harvest and give thanks to the goddess of Ala (the mother earth goddess). The Igbo believe that Ala is in charge of the blessings of the bountiful harvest of farm produce. The Ikeji festival is a long held tradition passed down through the ancestry of the Arondizougu clan emanating from Arochukwu in Abia state. It is an annual festival of the entire Aro kingdom spread alongside the South-Eastern part of Nigeria. The festival is an annual home coming ceremony and gathering of the Aro descendants from home and abroad to give thanks to God for making them see the New Year. There are festivals that celebrate the coming of age and fattening ceremonies, which culminate in marriage. These festivals and other theatrical activities practiced by the Igbo people are made manifest in their dance, music and drama. In the Igbo theatrical performances, all the important occurrences of nature, the day, phases of the moon, the seasons of the year, and the crisis of existence from birth to death are themes that are suggestive of the entire range of significant actions in human life. This perhaps gave rise to Oyewo's (2002: p. 104) submission that "the theatre is considered to be the most manifest medium expressing a cultural essence because it is usually a chronicle of human experience”.

\section{The Theatre}

According to Christopher Balme, the term "theatre" has its origin in the Greek word "theatron", meaning a "place for looking”. Thus, originally, theatre referred to both a place as well as to a particular form of sense perception. Balme observes today, the concept of "theatre” can refer to 1) a building; 2) an activity ("going to" or "doing” theatre); 3) an institution; and, 4) more narrowly, an art form (Balme, 2008). Balme notes the terminological complexity of the term means that the object of theatre studies is multi-dimensional and composed of many different fields of inquiries and scholarly perspectives.

This paper is concerned with the activities and art forms that take place before the spectators. Some of the activities were often performed as drama, music, dance and dramatic performances as a branch of art or as an institution (masquerading as a theatre, mmanwu institution) that makes use cultural instruments/heritage. These art forms make use of properties (props), costumes and makeup during their performances.

\section{Igbo Theatre}

The theatre is very relevant to Igbo arts and culture, whether as a place for viewing plays, dance, music and other spectacles or as a branch of art or an institution. Folk theatrical performances have been very popular in Igbo society from time in memorial. In fact, because of the commercial nature of their existence most of what they do are theatrical and the audience involved in the acting, dance, drama, music, folktales, wrestling, masquerading, festival and ritual performances etc. the village arena and the market square provided ready open air theatre. Special market days were reserved for such performances and renowned artistes enjoy a pride of place. For instance nothing stopped a good maiden dancer from getting married to a respectable member of the community, after a wonderful performance within living memory, good examples can be found. On the other hand, the best wrestler of the day had the most beautiful girl in the wrestling arena.

In contemporary society and specifically in Africa, the theatre is increasingly becoming very popular and 
therefore a most effective method of popularizing a people's culture. In most countries of the world, the Arts Councils, Museums and Archives and other cultural establishments are utilizing theatrical styles in popularizing, upholding and preserving the arts and culture of their people. Echeruo (1981), writing on theatre and ritual, opines that it is a dominant view amongst historians of drama whether it is in the European traditional, or in the African context, that conventional drama evolved from ritual. This is because many people today are so busy and often bored that they need relaxation and entertainment of excellent quality. It is for these reasons that practitioners of arts and culture should package excellent theatrical performances loaded with information on their arts and culture for consumption within and outside their environment. The British Art Councils, Germany Goethe Centre's and French Cultural Attaches are very well known for this.

The greatest danger facing Igbo arts and culture today is that of extinction in the mist of competing cultures. Having suffered destruction, degradation and looting during the colonial era and in fact during the civil war, Igbo culture deserves a lot of attention. Understandably the Igbo in their attempt to catch up with other Nigerians in different areas of their national life has tended to neglect their culture. Though the articulation and setting up of Arts and Culture in the Igbo speaking states is helping especially the younger generation for example, the Imo state government has introduced Ahiajoku lecture series, Ozuruimo cultural festival, Anu journal and Igbo dictionary.

A situation where the Igbo artistes pride themselves in mimicking western soap-opera and raps does not augur well for their culture. This trend is beginning to have adverse effect on their culture but could be controlled. I see a limitless sphere for the Igbo and Nigerian artistes, drawing inspiration from their rich arts and culture. For example, Igbo literature is lying dormant in their archives and memory within and outside the country and may be perpetually forgotten as useless past time of a primitive people. It was and is now even more popular to perform folktales all over the world. Igbo folktales, songs and poetry are rich and intellectual by any standard. They are genres of Igbo oral tradition through which a lot can be understood about Igbo life. There is hardly any Igbo tale that does not entertain as well as teach. They teach Igbo morals, names of objects-household, occupational and other materials, Igbo world view, Igbo history, origin and migration, their wars and heroes etc. It is therefore suicidal to allow this genre of Igbo literature to languish in the archives or be lost in their memories.

A community theatre like the Mmanwu (Masquerade) does not only teach the poetry of the Igbo-praise, satire and dirge, nor dance with its intricate steps, but give an insight into Igbo laws, their enforcement, and citizenship role in general. Mmanwu therefore is a total expression of the artistic and cultural skills of the Igbo. For an example the beauty of Ijere masquerade is total, Igbo expression of the universe in motion. Mmanwu performance for local and foreign consumption is very effective way of preserving the arts and culture of Igbo people.

The influence of foreign culture is negatively affecting our young artists and their performances on stage. Some of the performers in Igbo society feel ashamed to identify themselves with indigenous Igbo props, costumes and make-up even when they are performing indigenous plays with Igbo setting. Such artists prefer to identify and play with Western originated props, costumes and make-up. The theatre and productions of music, drama and dance can effectively be used to project, promote and preserve our cultural heritage. Theatre artist should carry out research in order to make an effective use of our indigenous props, costumes and make-up in the proper and correct manners. The Arts Councils and local troupes must sensitise and encourage the use of indigenous artefacts and crafts in the execution of theatre productions.

Igbo stage plays are generally eroding away in the theatre scene. Most of the artist could not speak or act through Igbo language effectively. However, the film/home video artists are trying in the production of Igbo films. The theatre and performing arts departments in tertiary institutions must encourage the performance of play productions in Igbo language. Igbo festivals are important events in the life of the people. They mark the passing of the season Igo-Afo (for blessing of farm increase in the new-year) attainment of statue by an Igbo individual or group (Ichi-Ozo and Iwa-akwa).

\section{Conclusion}

The work of art may be in the form of printing, sculpture, dance, music, literature or drama etc. This constitutes what Tolstoy calls "external signs". It could be written or oral, it could be expressed in objective or verbal form, it could be apprehended through sight or hearing in whatever form it may be put, the work of art could be regarded as objective representation of the artist's feelings and experiences. They artistes should reach out by performing them in modern theatrical standards which they meet. The same is true of their songs and poetry, riddles 
and proverbs etc. To say the least, the blending of these in any one performance would be wonderful and will help to promote and uphold our cultural heritage.

\section{References}

Achebe, C. (1980). Things Fall Apart. London: Heinemann Educational Books.

Afigbo, A. E. (1981). Ropes of Sand: Studies in Igbo History and Culture. Nsukka: University Press.

Afigbo, A. E. (1987). The Igbo and Their Neighbour: Inter-Group Relation in South-Eastern Nigeria. Ibadan: University Press.

Amankulor, J. (2002). The Art of Dramatic Art in Igboland. In G. Ofomata (Ed.), A Survey of the Igbo Nation (pp. 399-412). Onisha: Africana First Publishers Limited.

Aniako, C. C. (2002). Art in the Culture of Igboland. In: G. Ofomata (Ed.), A Survey of Igbo Nation (pp. 300-349). Onisha: African First Pubblishers Ltd.

Bakare, O. (2006). The Contemporary Choreography in Nigeria: A Realistic Culture Preserver or a Harmful Distortionist? In A. Yerima, B. Rasaki, \& A. Udoka (Eds.), Critical Perspectives on Dance in Nigeria (pp. 64-75). Ibadan: Kraft Books Limited.

Balme, C. (2008). The Cambridge Introduction to Theatre Studies. Cambridge: Cambridge University Press. http://dx.doi.org/10.1017/CBO9780511817021

Cycle, B. C. (1995). Igbo Leaders Allege Persecution in Nigeria. Reuters, 12 January, 17.

Echeruo, M. (1981). The Dramatic Limits of Igbo Ritual. In O. Yemi (Ed.), Drama and Theatre in Nigeria: A Critical Source Book (pp.136-148). Lagos: Nigerian Magazine.

Emeana, R. (2005). Theatre, Propaganda and War: The Biafran Armed Forces Theatre Experience. Nigerian Theatre Journal, 8.

Ezeabasili, N. (1982). Traditional Igbo Ideas about Disease and Its Treatment. In O. A. Erinso (Ed.), Nigerian Perspective on Medical Sociology (pp.17-28). Virginia: Department of Anthropology, College of William and Mary.

Federal Republic of Nigeria (1998). A Cultural Policy for Nigeria. Lagos: Federal Government Press.

Ihejirika, C. (2010). Ndi-Igbo in Nigeria: A Quest for Survival and Prosperity. A KCKCC E-Journal Exploring Scholarly Community.

http://www.kckcc.edu/ejournal/archives/october2010/article/NdiigboInNigeriaAQuestForSurvivalAndProsperity.aspx/

Ikiddeh, I. (2005). Historic Essay on African Literature, Language and Culture. Lagos: Minders International Publishers.

Isichei, E. (1976). A History of the Igbo People. New York: Macmillan.

Njoku, C. (2009). History and Culture of Mbaise (2nd, ed.). Aba: CELAJU Nig. Publishers.

Ogbaa, K. (1995). Igbo: Heritage Library of African Peoples. New York: Rosen Publishing Group.

Ohadike, D. C. (1994). Anioma: A Social History of the Western Igbo People. Ohio: Ohio University Press.

Omekwu, C. O. (2003). Information Technology Revolution, Libraries and Cultural Values: Issues, Impacts and Inevitable Challenges for Africa. Proceedings of the 69th IFLA General Conference and Council, Berlin, 1-9 August 2003.

Onwuejeogwu, M. A. (1978). Evolutionary Trend in the History of the Development of the Igbo Civilization, in the Culture Theatre of Igboland in Southern Nigeria. Ahiajoku Lecturer, Owerri: Culture Division Publication.

Onwuejeogwu, M. A. (1975). The Igbo Culture Area. In: F. C. Ogbalu, \& E. N. Emenanjo (Eds.), Igbo Language and Culture (pp. 1-10). Ibadan: Oxford University Press.

Oyewo, S. O. (2002). The Theatre in Nigeria’s Cultural Diplomacy. In: A. Yerimah, \& A. Akinwale (Eds.), The Problem of Dialogue Theatre and Democracy (pp. 104-114). Ibadan: Kraft Books Ltd.

The Oxford Dictionary of Language Matters (2015). Culture. Oxford: Oxford University Press. http://www.oxforddictionaries.com/definition/english/culture

Ukaegbu, V. (2007). The Use of Masks in Igbo Theatre in Nigeria: The Aesthetic Flexibility of Performance Traditions. Lewiston, NY: Edwin Mellen Press.

World Directory of Minorities (1997). Harlow: Longman Group. 